\title{
Host country corruption and the organization of HQ-subsidiary relationships
}

\author{
Rabbiosi, Larissa; Santangelo, Grazia D.
}

\author{
Document Version \\ Accepted author manuscript \\ Published in: \\ Journal of International Business Studies \\ DOI: \\ 10.1057/s41267-018-0169-1 \\ Publication date: \\ 2019 \\ License \\ Unspecified
}

Citation for published version (APA):

Rabbiosi, L., \& Santangelo, G. D. (2019). Host country corruption and the organization of HQ-subsidiary relationships. Journal of International Business Studies, 50(1), 111-124. https://doi.org/10.1057/s41267-0180169-1

Link to publication in CBS Research Portal

\section{General rights}

Copyright and moral rights for the publications made accessible in the public portal are retained by the authors and/or other copyright owners and it is a condition of accessing publications that users recognise and abide by the legal requirements associated with these rights.

\section{Take down policy}

If you believe that this document breaches copyright please contact us (research.lib@cbs.dk) providing details, and we will remove access to the work immediately and investigate your claim.

Download date: 26. Apr. 2023

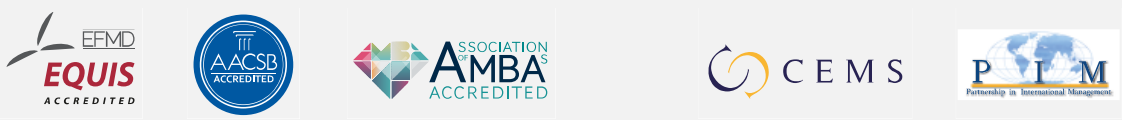




\section{Host country corruption and the organization of HO- subsidiary relationships}

Larissa Rabbiosi and Grazia D. Santangelo

Journal article (Accepted version*)

\section{Please cite this article as:}

Rabbiosi, L., \& Santangelo, G. D. (2019). Host country corruption and the organization of HQ-subsidiary relationships. Journal of International Business Studies, 501), 111-124. D01: 10.1057/s41267-018-0169-1

This is a post-peer-review, pre-copyedit version of an article published in Journal of International Business Studies. The final authenticated version is available online at: $\mathrm{https://doi.org/10.1057/s41267-018-0169-1}$

* This version of the article has been accepted for publication and undergone full peer review but has not been through the copyediting, typesetting, pagination and proofreading process, which may lead to differences between this version and the publisher's final version AKA Version of Record.

Uploaded to CBS Research Portal: May २०19 


\title{
HOST COUNTRY CORRUPTION AND THE ORGANIZATION OF HQ-SUBSIDIARY RELATIONSHIPS
}

\author{
Larissa Rabbiosi \\ Department of International Economics and Management \\ Copenhagen Business School \\ Porcelaenshaven 24A, DK2000 \\ Frederiksberg, Denmark \\ E-mail: $\underline{\text { r.int @ cbs.dk }}$ \\ Voice: +45 38152897 \\ Grazia Santangelo \\ Department of Strategic Management and Globalization \\ Copenhagen Business School \\ Kilevej 14, 2000 Frederiksberg, Denmark \\ E-mail: gs.smg@cbs.dk \\ and \\ Department of Political and Social Science \\ University of Catania (Italy) \\ Via Vittorio Emanuele 8, 95131 Catania, Italy
}

Running title: "Corruption and HQ-Subsidiary relations" 


\title{
Host country corruption and the organization of HQ-subsidiary relationships
}

\begin{abstract}
Multinational enterprises (MNEs) operating in more corrupt host (than home) countries face actual costs related to processing information for decision-making, and lack of local legitimacy, and potential reputation and legal costs in case of corruption scandals. Drawing on the organizational perspective of corruption, we argue that greater subsidiary autonomy helps minimize these costs. However, headquarter (HQ)-subsidiary communication weakens the autonomy-based advantages for minimizing legitimacy costs, and MNEs' experience in relatively corrupt countries the advantages for minimizing information-processing costs. Our analysis of 261 Italian foreign subsidiaries in 25 host countries confirms most of our arguments except the moderating effect of MNE experience. Our findings contribute to research on corruption and FDI, weak institutional contexts and MNE strategies as well as the literature on HQ-subsidiary relationship.
\end{abstract}

Keywords: Corruption; headquarters-subsidiary relations; subsidiary autonomy; dissociation strategy; organizational perspective of corruption. 


\section{INTRODUCTION}

Public corruption is the exercise of public power for private gain and includes both petty and grand forms of corruption, and state "capture" by elites and private interests (Kaufmann, Kraay, \& Mastruzzi, 2005). Corruption in host countries raises the barriers to entry and poses multiple challenges for multinational enterprises (MNEs) originating in countries with lower tolerance of corruption (Cuervo-Cazurra, 2006). These MNEs tend either to avoid entering relatively corrupt host countries, or tailor their entry modes to minimize exposing their equity to corruption and associated costs (e.g., Rodriguez, Uhlenbruck, \& Eden, 2005; Sartor \& Beamish, 2018; Uhlenbruck, Rodriguez, Doh, \& Eden, 2006; Wei, 2000). However, it is not always possible to reduce the percentage of equity, and for strategic reasons the MNE might need to establish a majority- or wholly-owned subsidiary in a host country with a level of corruption higher than in its home country. This poses the question of how MNEs organize their headquarters (HQ)-subsidiary relationships to operate in a relatively corrupt host country.

To investigate this issue, we examine how having subsidiaries in host countries that are more corrupt than the home country relates to the allocation of decision-making authority within the HQsubsidiary dyad. Drawing on an organizational perspective of corruption (Luo, 2002; 2005), we expect subsidiaries in relatively corrupt host countries will have greater autonomy because this will reduce the MNE's actual costs of processing and using decentralized information for decision-making, and those of dealing with their lack of local legitimacy. In addition, greater subsidiary autonomy, by enabling an autonomy-based dissociation strategy, allows the MNE to reduce the potential legal and reputational costs were the local subsidiary to be implicated in a corruption scandal. However, in a context of frequent HQsubsidiary communication, local legitimacy advantages and the credibility derived from a dissociation strategy linked to subsidiary autonomy, will reduce because of the inconsistencies in internal structures, policies, and practices that may be generated by conflicting institutional pressures from the home and host countries (Kostova, Roth, \& Dacin, 2008). Thus, we argue that HQ-subsidiary communication weakens the effect of relative host country corruption on subsidiary autonomy. We suggest also that MNE experience in relatively corrupt host countries will reduce the autonomy-based advantages related to information 
processing. The cumulated knowledge about how to operate in corrupt institutional contexts will enable the MNE to process and use information effectively for decision-making (Eriksson, Johanson, Majkgard , \& Sharma, 1997; Johanson \& Vahlne, 1977), and to develop corporate policies and practices to limit the subsidiary's involvement in wrongdoing. Thus, we expect that greater MNE experience in more corrupt countries will weaken the effect of relative host country corruption on subsidiary autonomy.

We test our hypotheses on a sample of 261 Italian foreign subsidiaries located in 25 different host countries. We find support for most of our arguments except for the moderating role of MNEs' experience in corrupt countries.

The literature on the organization of HQ-subsidiary relationships emphasizes internal drivers of autonomy such as MNE and subsidiary size, entry mode, and subsidiary age and mandate (e.g., Ambos \& Schlegelmilch, 2007; Gates \& Egelhoff, 1986; Nobel \& Birkinshaw, 1998). Studies from a business network perspective (Forsgren, Holm, \& Johanson, 2005) shift the focus to the relationship between external local factors and subsidiary autonomy, and shows that local embeddedness of the foreign subsidiary influences its autonomy (e.g., Ambos, Asakawa, \& Ambos, 2011). Host country characteristics and institutional factors have also been linked to aspects of subsidiary operations (e.g., Asmussen, Pedersen, \& Dhanaraj, 2009; Kuemmerle, 1999) although corruption as a relevant institutional factor seems to have been overlooked. In line with previous work, we focus on external drivers of the allocation of decisionmaking authority within the HQ-subsidiary relationship. However, in contrast with this body of work, we focus on host country corruption whose effect on the organization of HQ-subsidiary relationships seems to have been mostly unacknowledged (Luo, 2002; 2005). Within this framework, our study contributes to work on the relationship between corruption and FDI by relating the host country's relative level of corruption to the MNEs' organizational structure. We add to research on weak institutional contexts and MNE strategies by shedding light on HQ-subsidiary relationships as a strategic dimension that so far has been overlooked. Finally, we contribute to research on subsidiary autonomy by highlighting the relevance of external institutional determinants. We also make an empirical contribution by proposing a corruption measure to account for directionality and asymmetry. 


\section{THEORETICAL DEVELOPMENT}

MNEs from countries with low tolerance for corruption may be ill-equipped to operate in a more corrupt country. For these MNEs, corruption is likely to increase the costs of processing and using information for decision-making about day-to-day operations (i.e. information-processing costs) and the costs associated to lack of local legitimacy (i.e. legitimacy costs). In situations where public corruption is endemic, in order to support their decision-making firms originating from countries with low tolerance of corruption need to process information and knowledge on aspects of the local business environment not manifest in formal laws, rules, and regulations accessible to foreign and domestic actors alike (Cuervo-Cazurra, 2006). For instance, it is not uncommon for entrenched cultural norms characterized by strong interpersonal relations such as guanxi (Chinese) or inhwa (Korean) to be the basis for business negotiations (Luo, 2002). While the distinction between different social norms and standards, and corruption, may be evident to the locals it can be far less clear to foreign firms (Luo, 2002). Decision-making also will require information about how to avoid and limit the subsidiary's exposure to illegal requests for payments from corrupt officials (Doh, Rodriguez, Uhlenbruck, Collins, \& Eden, 2003). Thus, MNEs from countries with low tolerance for corruption will face additional costs for processing information required for decisions about day-to-day operations. Also, MNEs from countries with low tolerance of corruption are likely to face additional costs associated to lack of legitimacy which is required to operate within a host society where the cognitive and normative isomorphic pressures to comply with local practices, structures and policies are markedly different from those in the home country (Eden \& Miller, 2004; Kostova, 1999; Spencer \& Gomez, 2011). Failing to follow culturally-accepted practices such as providing gifts to government officials can render the foreign firm an illegitimate partner (Cuervo-Cazurra, 2016). In such contexts, lack of familiarity with local expectations can result in MNEs from countries with low tolerance for corruption suffering lack of local legitimacy resulting in discrimination and adverse treatment from host country stakeholders (Luo \& Shenkar, 2011).

In addition to the actual costs of information-processing and lack of legitimacy, MNEs operating in relatively corrupt host countries face potential costs associated to the risk of being implicated in corrupt 
behavior (Spencer \& Gomez, 2011). These include legal (accusations, law suits, penalties, fines, etc.) as well as reputation costs related to a negative corporate image were the MNE's local subsidiary to be implicated in wrongdoing (Luo, 2005). Alleged corruption involving a foreign subsidiary can threaten the reputation of the entire MNE; the interdependence of geographically dispersed MNE units makes them vulnerable to negative legitimacy spillovers (Kostova \& Roth, 2002). These spillovers occur because corruption is subject to intense worldwide scrutiny, and an MNE unit's violation of the home country's expectations can result in substantial negative publicity for the entire MNE (Kostova \& Zaheer, 1999). Failure to meet corporate expectations of clean conduct from the MNE's subsidiaries can result in huge reputation costs for the MNE which translate into financial losses and reduced firm performance (Spencer \& Gomez, 2011). Potential reputation costs are a major concern for MNEs which in the current context of a backlash against globalization face continuous requests for corporate responsible conduct (Contractor, 2017), and rely on forward-looking strategies such as specialized anti-bribery and corruption services provided by large consulting companies to safeguard corporate reputation and ensure stability and competitive position.

\section{Corruption and Subsidiary Autonomy}

Efficient information processing, and local legitimacy assume great importance in the response to environmental complexities in corrupt host countries (Luo, 2005). Decentralized decision-making can be expected to minimize both information-processing and legitimacy costs, and effectively ease the conduct of business by MNEs in relatively corrupt host countries. If the level of host country corruption increases, centralized decision-making increases the cost of information processing (e.g., Egelhoff, 1993). Centralization requires the MNE to build capacity to enable observation of the environment, and to process information critical to an understanding of how government agents enable, facilitate, and enforce external transactions. At the same time, decision-making based on the limited information available in the HQ is likely to paralyze subsidiary operations, and ultimately, to increase the risk of exit from the host country. More autonomous foreign subsidiaries are able to conduct more efficient information acquisition, assessment, monitoring, and exchange (Birkinshaw \& Hood, 1998), and to use this information for their 
decision-making processes (Egelhoff, 1993). In addition, in the case of subsidiaries operating in relatively corrupt host countries, centralized decision-making raises the cost associated to lack of local legitimacy. Centralization makes it difficult, if not impossible, for the HQ to deal with diverse cultural norms, cognitive structures, and operating models to satisfy local expectations and be regarded as legitimate partners in all of the countries where they have subsidiaries (Westney \& Zaheer, 2001). This is a particularly acute issue for MNEs with subsidiaries operating in culturally distant countries (Hoenen \& Kostova, 2015). Decentralization of decision-making authority enables local subsidiaries to comply with the cognitive and normative distinctiveness of the local environment, and thus, reduces unfamiliarity with local needs and expectations and limits discrimination and adverse treatment from host country stakeholders. More autonomous subsidiaries are better positioned to acquire a sense of the legitimate ways to establish relationships and networking in the host country, which may differ from those culturally accepted in the home country (Cuervo-Cazurra, 2016).

Subsidiary autonomy in countries with higher tolerance of corruption allows use of a forwardlooking strategy that helps to minimize the potential reputation and legal costs associated to the risk of potential involvement in corruption scandals surrounding the foreign subsidiary's operations. If a relatively autonomous foreign subsidiary is implicated in a bribery investigation, the MNE can distance itself from the subsidiary's stigmatizing corrupt behavior, and defend its reputation on the grounds of decentralized decision-making authority within the HQ-subsidiary relationship. This dissociation strategy will be reflected in the MNE's media announcements and communication activities aimed at mitigating reputation costs based on subsidiary autonomy. Subsidiary autonomy is an enduring structural characteristic of the HQ-subsidiary dyad which renders the MNE's dissociation from the subsidiary's alleged actions more credible. For instance, in a press release related to the case of U.S. v. Pfizer H.C.P. Corp. (August, 2012), the company stated:

"There is no allegation by either [Department of Justice] DOJ or [Securities and Exchange Commission] SEC that anyone at Pfizer's or Wyeth's corporate headquarters knew of or approved [emphasis added] the conduct at issue before Pfizer took appropriate action to investigate and report it."1 
In this statement the dissociation emerges in Pfizer's declaration of anyone at the corporate HQ knowing about the Chinese subsidiary's wrongdoing. Pfizer's dissociation from the subsidiary's behavior was reflected in several media announcements:

"Pfizer Inc. agreed Tuesday to pay $\$ 60$ million to settle charges alleging that some of its foreign subsidiaries bribed [emphasis added] doctors and health-care officials ... No one at Pfizer headquarters knew of the bribery [emphasis added], regulators [SEC and DOJ] said."'

"Pfizer Inc., the world's biggest drugmaker, agreed to pay $\$ 60.2$ million to settle foreign bribery cases it brought to U.S. authorities involving alleged payments paid by employees and agents of subsidiaries [emphasis added]."3

Similarly, in the case of U.S. v. Alcatel-Lucent S.A. (December, 2010) Steve Reynolds, Alcatel-Lucent General Counsel, in a press release said:

"In addition, three Alcatel-Lucent subsidiaries will each plead guilty [emphasis added] to a criminal information charging one count of conspiracy to commit anti-bribery, books and records, and internal controls violations of the FCPA"4,

and the media reported that:

“Alcatel's 'de-centralized business structure' which permitted different Alcatel employees around the world [emphasis added] 'to initially vet the third-party consultants, and then rely on Executive 1 [a French citizen who served as Chief Executive Officer of Alcatel Standard in Basel, Switzerland] at Alcatel to perform due diligence on them.' ... The company admitted subsidiaries made improper payments [emphasis added] to obtain and retain business in Taiwan, Malaysia, Costa Rica and Honduras."

By compartmentalizing the identities of the parent company, and its foreign subsidiaries, the MNE can shift the blame from the whole enterprise to the foreign subsidiary (Spencer \& Gomez, 2011). Although delegation of decision-making authority does not remove the MNE's legal liability for its subsidiary's conduct, it is not uncommon for evidence of decentralization to be included in legal documentation (e.g., US DOJ/US SEC press release, settled complaints, criminal information) and cited as an extenuating circumstance in the MNE's failure to identify its foreign unit's wrongdoing. Thus, we predict that:

Hypothesis 1: The higher the degree of corruption in the host country relative to the home country, the higher will be the level of foreign subsidiary autonomy.

Structures, policies, and practices institutionalized within the MNE tend to be imprinted by the external institutional environment in which the organization was founded (home country) (Kogut, 1993). 
At the same time, MNE units are exposed to host country pressures (Kostova et al., 2008). These multiple institutional pressures can create internal inconsistencies if the subsidiary adopts different structures, policies, and practices in an effort to limit legitimacy costs in the host country (DiMaggio \& Powel, 1983; Rosenzweig \& Singh, 1991).

Communication between HQ and subsidiary is effected by personal-based and electronic means, and acts as a coordination mechanism to facilitate knowledge exchange and creation (e.g., Fulk \& DeSanctis, 1995; Nobel \& Birkinshaw, 1998). Typically, intra-MNE communication is used as a means to indirectly channel and filter isomorphic pressure from the MNE's home country institutional environment to the foreign subsidiary (Harzing \& Sorge, 2003; Kogut, 1993; Kostova \& Roth, 2002). However, intraMNE communication also makes the norms and practices in individual units more observable, and eventually, favors the emergence of intra-MNE inconsistencies (Rosenzweig \& Singh, 1991). Thus, in relatively corrupt environments, the more intense the communication between HQ and the foreign subsidiary, the more evident will be the coexistence within the MNE of different practices to relate and respond to corrupt requests, business negotiating styles, engagement in interpersonal relationships, etc.. Internal inconsistencies are likely to create a trade-off between the perceived benefits generated by subsidiary autonomy in dealing with legitimacy costs, and the increased internal inconsistencies which can harm the MNE's organizational capability and competitive advantage worldwide (Ghoshal \& Bartlett, 1988; Grant, 1996; Kogut, 1993; Nohria \& Ghoshal, 1997).

In addition, in relation to internal inconsistencies, higher levels of internal communication will render an MNE dissociation strategy based on subsidiary autonomy less effective for reducing potential reputation and legal costs. HQs that communicate intensively with their subsidiaries located in countries with higher tolerance for corruption will lose credibility in the eyes of their stakeholders, and face high reputation and legal costs should they "plead ignorance" of their subsidiaries' operations. In fact, high levels of communication between HQ and subsidiary increase awareness of the subsidiary's local operations, and create the conditions for the enforcement of corporate anti-corruption policies. Thus, with intense HQ- 
subsidiary communication the potential advantage of a dissociation strategy is reduced since the HQ is unable to distance itself from its subsidiary's potential involvement in corrupt behavior.

High HQ-subsidiary communication will reduce the benefits that subsidiary autonomy can bring in terms of actual legitimacy costs, and potential reputation and legal costs. Hence, we expect HQ-subsidiary communication to moderate the relationship between corruption and autonomy such that the effect of host country corruption on subsidiary autonomy decreases in situations of intense HQ-subsidiary communication. We predict that:

Hypothesis 2: The higher the level of communication between the HQ and its subsidiaries located in relatively corrupt host countries, the weaker will be the (positive) relationship between the degree of corruption in the host country relative to the home country, and subsidiary autonomy.

International experience enables firms to limit their knowledge disadvantages when expanding into new markets (Barkema, Bell, \& Pennings, 1996; Johanson \& Vahlne, 1977; Makino \& Delios, 1996). Knowledge about foreign business and institutions reduces internationalization costs because firms acquire experiential knowledge (Eriksson et al., 1997).

Likewise, MNEs' experience in more corrupt countries increases knowledge about how to handle corrupt practices abroad (Rodriguez et al., 2005). Given the higher level of tacitness of the knowledge concerning corruption, MNE's direct experience can be very valuable. This often requires learning about informal and unwritten norms, practices, and procedures (Cuervo-Cazurra, 2006). For instance, familiarity with how to identify and deal with various (corrupt) stakeholders, and understanding differences in corrupt practices, can be developed in the course of investment in different corrupt markets. Thus, experience in corrupt environments leads to the accumulation of knowledge about corrupt practices which may be useful for other corrupt country contexts. As a result, MNEs with FDI experience in more corrupt countries will have less need to delegate decision-making authority to subsidiaries operating in countries with higher tolerance for corruption. These MNEs can leverage their experiential knowledge to minimize the information-processing costs related to decision-making, and to perform day-to-day operations efficiently. However, it is unlikely that experience of challenges to legitimacy specific to a (relatively corrupt) host 
country will help to limit legitimacy costs in a different (relatively corrupt) host country since isomorphic behaviors to achieve legitimacy are likely to be country-specific.

In addition, MNEs' experience in more corrupt host countries may trigger the development and implementation of anti-corruption corporate policies and practices (as opposed to an autonomy-based dissociation strategy) to limit reputational and legal costs due to potential subsidiary wrongdoing and involvement in corruption scandals. To sum up, we expect that the effect of host country corruption on subsidiary autonomy will decrease with the MNE's experience in corrupt countries, and we predict that:

Hypothesis 3: The greater the MNE's experience in relatively corrupt host countries, the weaker will be the (positive) relationship between the degree of corruption in the host country relative to the home country, and subsidiary autonomy.

\section{METHOD}

\section{Data}

Foreign subsidiaries of Italian MNEs during the period 2004-2005 provide an appropriate empirical context for our study. Although Italy subscribes to the OECD Convention on Combating Bribery of Foreign Public Officials in International Business Transactions, in 2004-2005 it was positioned roughly in the middle of the world country rankings for corruption (Kaufmann et al., 2005).

We exploit a survey conducted in 2004 and 2005 on a sample of 358 MNEs which is the population of all Italian manufacturing MNEs with more than 50 employees and with at least one majority-owned subsidiary involved in "primary upstream activities" (e.g., R\&D, manufacturing) located in an advanced country at the beginning of 2004. Eighty-four MNEs and their parent company top managers agreed to participate in on-site, face-to-face structured interviews which allowed the collection of information on control and communication mechanisms used within the HQ-subsidiary relationship, based on closed questions. We gathered information on 293 parent-subsidiary dyads. Tests of representativeness show that with the exception of MNEs in supplier-dominated sectors which are underrepresented, the sample composition in terms of sector, size, and parent location is generally representative of the population of MNEs in Italy. Concerns about "parent-respondent-bias" were alleviated by administration of a survey 
involving 68 of the subsidiaries that participated in the first data collection round. Completed questionnaires were returned by 62 subsidiaries, and for consistency, the recorded responses from subsidiary managers where compared to those provided by the managers at the MNE parent (for more details on the data, see Mudambi, Piscitello, \& Rabbiosi, 2014).

We matched our survey data to the World Governance Indicators (WGI) control of corruption index (Kaufmann et al., 2005) which ranges from minus 2.5 (weak control over corruption) to 2.5 (strong control over corruption). To simplify interpretation of the coefficients, we rescaled the index by subtracting the original index from 2.5, such that higher numbers indicate higher levels of corruption, and lower numbers indicate lower levels of corruption (e.g., Cuervo-Cazurra, 2006). We relied also on the World Development Indicators (WDI) and the 2004 International Property Rights Index (IPRI) for additional host and home country data. Matching the 293 HQ-subsidiary dyads to the corruption index resulted in 277 foreign subsidiaries being retained. Missing information for additional countries in the WDI and IPRI data reduced the sample size to $261 \mathrm{HQ}$-foreign subsidiary dyads, and 25 host countries dispersed across the world. ${ }^{6}$

\section{Measures}

We asked respondents to rank the level of subsidiary involvement in four strategic decisions vis-à-vis HQ influence (e.g., Ghoshal, Korine, \& Szulanski, 1994): definition of R\&D projects, planning, resources, etc.; introduction of new technologies; changes to products/services; and hiring and firing of subsidiary workforce. Subsidiary/HQ involvement for each decision was measured on a 1-5 scale (from "parent company decides alone" to "subsidiary decides alone"). Subsidiary autonomy is the average of the responses to the four decisions (Cronbach's alpha $=0.75)$.

To test our hypotheses, we allow explicitly for the direction of corruption distance based on recent calls for directionality and asymmetry in distance measures (e.g., Zaheer, Schomaker, \& Nachum, 2012). Thus, we calculate positive and negative corruption distances. In particular, we take the squared difference between the rescaled control corruption index values for each home-host country pair, Italy being the home country (Siegel, Licht, \& Schwartz, 2013). The quadratic form of this measure assumes that the higher the corruption distance between home and host countries, the greater the marginal difficulties involved in 
acquiring and processing local knowledge associated to an additional unit of distance. We then split corruption distance into two additional variables (Tsang \& Yip, 2007): positive corruption distance measured as $\left(\mathrm{C}_{\mathrm{J}}-\mathrm{C}_{\mathrm{IT}}\right)^{2}$ if $\mathrm{C}_{\mathrm{J}} \geq \mathrm{C}_{\mathrm{IT}}$ and equal to zero if $\mathrm{C}_{\mathrm{J}}<\mathrm{C}_{\mathrm{IT}}$, and negative corruption distance measured as $\left(C_{I T}-C_{J}\right)^{2}$ if $C_{I T} \geq C_{J}$ and equal to zero if $C_{I T}<C_{J}$, where $C_{J}$ is the rescaled WGI control of corruption index of the host country and $\mathrm{C}_{\mathrm{IT}}$ of Italy.

We measure the frequency of use of visits, teamwork, temporary (short-term) transfers of managers, temporary (short-term) transfers of scientific and technical staff (researchers, engineers, etc.), joint training activities, internet-based instruments such as forums, newsletters, e-mails, instant messages, etc., and exchange of documents such as handbooks, blueprints, and databases within the HQ-subsidiary dyad (e.g., Nobel \& Birkinshaw, 1998) on a seven-point Likert scale (from “rarely used" to "used very often"). Internal communication is the average of the responses to the seven items (Cronbach's alpha $=0.74$ ). We operationalize MNE experience in more corrupt countries as the number of the MNE's previous FDIs in countries with a corruption index value higher than the value for Italy.

As suggested in the literature on subsidiary autonomy, we control for the following variables. Subsidiary age is the logarithm of the difference between 2005 (the year the interviews were conducted) and the year that the subsidiary became part of the Italian MNE; subsidiary size is the subsidiary's annual sales (millions of EUR) in 2004; high-tech industries equals 1 if the subsidiary operates in "science-based" or "specialized supplier" sectors, with low-tech (i.e., "scale-intensive" and "supplier dominated") sectors (Pavitt, 1984) as the benchmark; the binary variable greenfield captures entry mode. Three binary variables operationalize the nature of the subsidiary's activities: implementers or subsidiaries not focused on activities aimed at the creation of new products and/or new technologies ("capability-augmenting activities"), nor on activities aimed at product or process improvements (“capability-exploiting activities”); contributors which are capability-exploiting but not capability-augmenting firms; and innovators which are capability-augmenting firms. Knowledge flows equals 1 if the focal subsidiary receives from and/or sends knowledge to its HQ. Cultural distance is measured using Kogut and Singh's (1988) cultural distance index. Geographical distance is the distance in (thousands of) kilometers between Rome and the capital city of the 
foreign subsidiary's country. Economic distance is the natural logarithm of the difference between the home and host countries' gross domestic product (GDP), and intellectual property rights distance is the difference in the home-host country IPRI. Host country knowledge sourcing opportunities are proxied by the squared of the positive difference in the knowledge intensity values for each home-host country pair, calculated via principal component factor analysis of two indicators: R\&D expenditure as a percentage of GDP, and number of published scientific and engineering articles per 1,000 inhabitants (source: WDI) (Cronbach's alpha $=0.92)$.

Table 1 summarizes the descriptive statistics and correlations.

- TABLE 1-

\section{RESULTS}

Table 2 reports the results of the ordinary least squares (OLS) estimations for subsidiary autonomy. We rule out problems of possible non-independence among the HQ-subsidiary dyads, clustering dyads involving the same MNE using Stata's cluster option.

\section{- TABLE 2-}

In Model 1, positive corruption distance has a positive and significant coefficient $(\mathrm{p}<0.05)$, indicating that the higher the level of corruption in the host country relative to the home country, the greater the foreign subsidiary's autonomy. This supports Hypothesis 1 which suggests that MNEs will attempt to reduce both actual information-processing and legitimacy costs, and potential reputation and legal costs in relatively corrupt countries by delegating decision-making authority to the foreign subsidiary. Negative corruption distance does not explain foreign subsidiary autonomy which corroborates the idea that ceteris paribus, there is no need for more autonomy to reduce corruption-related costs if subsidiaries are located in less corrupt countries. In Model 2, we test Hypothesis 2. The coefficient of the interaction term positive corruption distance $\times$ internal communication is negative and significant $(\mathrm{p}<0.05)$. That is, the effect of positive corruption distance on subsidiary autonomy reduces with higher levels of HQ-subsidiary communication. This confirms our expectation that by making intra-MNE inconsistencies in practices and policies visible, internal communication reduces the perceived benefits of subsidiary autonomy related to 
actual legitimacy costs and potential reputation and legal costs. Figure 1 depicts this significant moderating effect. In Model 3, we test the moderating effect of MNE experience in more corrupt countries on the effect of positive corruption distance on subsidiary autonomy. While, as hypothesized, the sign of the interaction term is negative, the estimated coefficient is not statistically significant. Thus, we find no empirical support for the argument that accumulated experience of operating in more corrupt countries is useful for reducing information-processing costs and potential reputation and legal costs related to later activity in more corrupt countries. In Model 4, to evaluate the stability of our results both interaction terms are included in the estimation. The results do not change: we find support for Hypotheses 1 and 2 but no support for Hypothesis 3.

\section{-FIGURE 1-}

We checked the robustness of our results to different measures of corruption distance. First, we used the non-squared home-host country positive and negative differences, followed by a corruption distance index which does not separate negative and positive distance. In both cases, our results were confirmed.

Since internal communication and subsidiary autonomy are correlated both directly and indirectly through third variables, the moderating effect of communication on the relationship between corruption and subsidiary autonomy might not be driven by the complementarity of internal communication to corruption distance. To check this, we exploit the properties of the linear regression estimation to "partial out" the effects of an independent and a dependent variable (Foss, Laursen, \& Pedersen, 2011). Specifically, we regress subsidiary autonomy on internal communication and compute the residuals, $\hat{\varepsilon}$. We also generated a new interaction term $\hat{\varepsilon} \times$ positive corruption distance. We use these variables based on predicted values to re-estimate Model 2 in Table 2. Model 5 confirms that higher levels of internal communication reduce the level of subsidiary autonomy associated to corruption. Since the residuals capture the internal communication variance not explained by subsidiary autonomy, we can envisage no other reason for the reduction in subsidiary autonomy suggested by the coefficient of the interaction term $\hat{\varepsilon} \times$ positive 
corruption distance than what is captured by the complementarity between higher levels of communication and corruption distance.

\section{DISCUSSION AND CONCLUSION}

Building on the idea that the challenges host country corruption poses to MNEs go beyond whether (and how) to enter the country (Luo, 2011) and encompass the MNE's organization (Luo, 2002; 2005), we study the relationship between host country relative corruption and subsidiary autonomy. We find that the greater the relative host country's level of corruption the higher the level of subsidiary autonomy. Specifically, our findings support the idea that a more decentralized organizational structure enables the MNE to process and use local information for decision-making more effectively, and limits the costs associated to lack of legitimacy. It also enables an autonomy-based dissociation strategy to minimize potential reputation and legal costs should the foreign subsidiary be implicated in a corruption scandal. However, a high level of intra-MNE communication makes subsidiary autonomy a less effective response to a relatively corrupt host environment because it reveals internal inconsistencies which reflect conflicting home and host country institutional pressures. This reduces the benefits of subsidiary autonomy associated to lower legitimacy costs and the potential implementation of a dissociation strategy. On the other hand, we found no evidence of MNE experience in more corrupt countries rendering subsidiary autonomy a less effective response for MNEs operating in relatively corrupt host environments. This is most likely because although knowledge gained through previous experience may be helpful, it does not substitute for the host country-specific knowledge (Eriksson et al., 1997) needed to reduce information-processing costs.

Our study contributes to research on subsidiary operations in corrupt countries. Research on host country public corruption and FDI often links the level of host country corruption, and the distance between the home and host country levels of corruption, to the decision to undertake FDI, and how to enter the host country (e.g., Cuervo-Cazurra, 2006; Habib \& Zurawicki, 2002; Rodriguez et al., 2005; Uhlenbruck et al., 2006). The main conclusions from these works are that corruption deters entry subject to certain conditions such as the relative level of corruption in the country of origin, and the entry mode which can be tailored strategically to the specific type of host country corruption. Corruption has been studied also in connection 
to post-entry strategies, and in particular, how corruption influences subsidiaries' investment commitments and export market orientation (Luo, 2011), and need to engage in bribery (Spencer \& Gomez, 2011). We add to this research by focusing on the organization of HQ-subsidiary relationships and relating corruption to the MNEs' organizational structure. We highlight a relationship between host country corruption and the MNE's organizational structure based on the idea that firms implement organizational strategies that minimize corruption-related costs. These are additional costs created by host country corruption related to processing information and addressing the lack of local legitimacy, and the reputation and legal costs incurred if the subsidiary is involved in a corruption scandal.

We contribute also to research on the impact of a weak institutional framework on MNEs' strategies. If the MNE is forced to operate in a foreign country through a wholly-owned subsidiary, the MNE's operational integration will be affected by a weak host country legal institutional framework (Feinberg \& Gupta, 2009). In particular, MNEs may arbitrage across countries with varying levels of institutional quality by strategic allocation of supervisory responsibility based on host country institutional quality, to enhance coordination within diverse global operations (Zhou 2014). Also, a weak host country institutional framework might result in adaptations to the MNE's operational and local collaboration strategies to respond to these institutional voids and uncertainties (Doh, Rodrigues, Saka-Helmhout, \& Makhija, 2017; Santangelo \& Meyer, 2011; Santangelo, Meyer, \& Jindra, 2016). Alternatively, MNEs may engage in the co-creation of a new institutional logic and encourage local employees embedded in the competing institutional logics to become key intermediaries (Newenham-Kahindi \& Stevens, 2017). In the context of work in this area, we propose the relevance of the subsidiary autonomy as an organizational strategy used by the MNEs against the inefficiencies and risks inherent in weak institutional contexts such those with higher tolerance of corruption.

Finally, we contribute to research on subsidiary autonomy which focuses primarily on autonomy driven by internal factors and the subsidiary's business network (e.g., Ambos \& Schlegelmilch, 2007; Forsgren et al., 2005; Gates \& Egelhoff, 1986). In this stream of work, HQ-subsidiary relations are investigated typically within a broader agency perspective starting from the idea that the subsidiary may 
not act in the best interests of the parent (for a review, see Hoenen \& Kostova, 2015). More recently, subsidiary autonomy has been related to home country institutions, and studied as a strategy for distancing the subsidiary administratively from the parent's negative home-country institutional heritage (Wang, Luo, Lu, Sun, \& Maksimov, 2014). We add to this research on the relevance of the host country's institutional context, and highlight corruption as a salient institutional determinant of the allocation of decision-making authority in HQ-subsidiary relationships. Moreover, since communication is often a tool of subtle control (Asakawa, 2001), our research helps enlarging the still few studies that differentiate between autonomy and monitoring (Ambos, Andersson, \& Birkinshaw, 2010; Asakawa, 2001; Bouquet \& Birkinshaw, 2008).

Our study also provides an empirical contribution by responding to a call for work on directionality and asymmetry in distance measures (e.g., Zaheer et al., 2012). The corruption literature tends to measure directionality by interacting investor's country of origin with a measure of the level of host country corruption (Cuervo-Cazurra, 2006). We extend this literature by proposing an asymmetric directional measure of corruption between the home and host countries that allows us to disentangle the different HQsubsidiary organizational responses.

Our study has some limitations due to potential unobserved heterogeneity which prevents predictions about a causal relation between positive corruption distance and subsidiary autonomy. Also, underrepresentation of the supplier-dominated sector limits the generalizability of our findings. However, our study suggests some directions for future research. Autonomy could be studied in relation to different characteristics (e.g. arbitrariness, pervasiveness) and types (e.g., private) of host country corruption (Rodriguez et al., 2005; Uhlenbruck et al., 2006). The relationship between subsidiary autonomy and host country corruption could be examined in relation to a broader spectrum of HQ-subsidiary characteristics. This might set new boundary conditions and further differentiate the roles of different types of corruptionrelated costs that emerge when MNEs operate in more corrupt host countries.

\section{ENDNOTES}


${ }^{1}$ Source: Pfizer Press release http://press.pfizer.com/press-release/pfizer-announces-resolutions-doj-and-sec-relatedcertain-international-operations.

${ }^{2}$ Source: The Washington Post. https://www.washingtonpost.com/business/economy/pfizer-agrees-to-pay-60m-tosettle-foreign-bribery-case/2012/08/07/a2426f5e-e0b6-11e1-8fc5-a7dcf1fc161d_story.html.

${ }^{3}$ Source: Bloomberg. http://www.bloomberg.com/news/articles/2012-08-07/pfizer-agrees-to-settle-foreign-briberycase-with-u-s-.

${ }^{4}$ Source: Alcatel Press release https://www.alcatel-lucent.com/press/2010/002305\#sthash.nok3QDPl.dpuf

${ }^{5}$ Source: Bloomberg. http://www.bloomberg.com/news/articles/2010-12-27/alcatel-lucent-will-pay-137-million-tosettle-u-s-bribery-investigations.

${ }^{6}$ The distribution of FDI is as follows: 59\% in Western Europe, 7\% in Eastern Europe, 16\% in North America, $8 \%$ in Central and South America, 9\% in Asia, and 1\% in Africa. 


\section{REFERENCES}

Ambos, B., Asakawa, K., \& Ambos, T. C. 2011. A dynamic perspective on subsidiary autonomy. Global Strategy Journal, 1(3-4): 301-316.

Ambos, B., \& Schlegelmilch, B. B. 2007. Innovation and control in the multinational firm: a comparison of political and contingency approaches. Strategic Management Journal, 28(5): 473-486.

Ambos, T., Andersson, U., \& Birkinshaw, J. 2010. What are the consequences of initiative taking in multinational subsidiaries? Journal of International Business Studies, 41(6): 1099-1118.

Asakawa, K. 2001. Organizational tension in international R\&D management: the case of Japanese firms. Research Policy, 30(5): 735-757.

Asmussen, C. G., Pedersen, T., \& Dhanaraj, C. 2009. Host-country environment and subsidiary competence: Extending the diamond network model. Journal of International Business Studies, 40(1): 4257.

Barkema, H. G., Bell, J. H. J., \& Pennings, J. M. 1996. Foreign entry, cultural barriers and learning. Strategic Management Journal, 17(2): 151-166.

Birkinshaw, J., \& Hood, N. 1998. Multinational subsidiary evolution: Capability and charter change in foreign-owned subsidiary companies. Academy of Management Review, 23(4): 773-795.

Bouquet, C., \& Birkinshaw, J. 2008. Weight versus voice: how foreign subsidiaries gain attention from corporate headquarters. Academy of Management Journal, 51(3): 577-601.

Contractor, F. J. 2017. Global Leadership in an Era of Growing Nationalism, Protectionism, and AntiGlobalization. Rutgers Busines Review, 2(2): 163-185.

Cuervo-Cazurra, A. 2016. Corruption in international business. Journal of World Business, 51(1): 35-49.

Cuervo-Cazurra, A. 2006. Who cares about corruption? Journal of International Business Studies, 37(6): 807-822.

DiMaggio, P., \& Powel, W. 1983. The Iron Cage Revisited: Institutional Isomorphism and Collective Rationality in Organizational Fields. American Sociological Review of Economics and Statistics, 48(2): 147-160.

Doh, J., Rodrigues, S., Saka-Helmhout, A., \& Makhija, M. 2017. International business responses to institutional voids. Journal of International Business Studies, 48(3): 293-307.

Doh, J. P., Rodriguez, P., Uhlenbruck, K., Collins, J., \& Eden, L. 2003. Coping with corruption in foreign markets. Academy of Management Executive, 17(3): 114-127.

Eden, L., \& Miller, S. R. 2004. Distance matters: Liability of foreignness, institutional distance and ownership strategy. In Hitt, M A \& J L Cheng, (Eds.), Theories of the Multinational Enterprise: Diversity, Complexity and Relevance (Advances in International Management, Volume 16): Emerald Group Publishing Limited. 
Egelhoff, W. G. 1993. Information-processing theory and the multinational corporation. In Ghoshal, Sumantra \& E Westney, (Eds.), Organization theory and the multinational corporation. New York: St Martin's Press.

Eriksson, K., Johanson, J., Majkgard , A., \& Sharma, D. D. 1997. Experiential Knowledge and Cost in the Internationalization Process. Journal of International Business Studies, 28(2): 337-360.

Feinberg, S. E., \& Gupta, A. K. 2009. MNC subsidiaries and country risk: internalization as a safeguard against weak external institutions. Academy of Management Journal, 52(2): 381-399.

Forsgren, M., Holm, U., \& Johanson, J. 2005. Managing the embedded multinational: A business network view. Cheltenham: Edward Elgar.

Foss, N. J., Laursen, K., \& Pedersen, T. 2011. Linking customer interaction and innovation: The mediating role of new organizational practices. Organization Science, 22(4): 980-999.

Fulk, J., \& DeSanctis, G. 1995. Electronic communication and changing organizational forms. Organization Science, 6(4): 337-349.

Gates, S. R., \& Egelhoff, W. G. 1986. Centralization in headquarters-subsidiary relationships. Journal of International Business Studies, 17(2): 71-92.

Ghoshal, S., \& Bartlett, C. A. 1988. Creation, adoption, and diffusion of innovations by subsidiaries of multinational corporations. Journal of International Business Studies, 19(3): 365-388.

Ghoshal, S., Korine, H., \& Szulanski, G. 1994. Interunit communication in multinational corporations. Management Science, 40(1): 96-110.

Grant, R. M. 1996. Toward a knowledge-based theory of the firm. Strategic Management Journal, 17(Winter special issue): 109-122.

Habib, M., \& Zurawicki, L. 2002. Corruption and Foreign Direct Investment. Journal of International Business Studies 33(2): 291-307.

Harzing, A. W., \& Sorge, A. 2003. The relative impact of country of origin and universal contingencies on internationalization strategies and corporate control in multinational enterprises: worldwide and European perspectives. Organization Studies, 24(2): 187-214.

Hoenen, A. K., \& Kostova, T. 2015. Utilizing the broader agency perspective for studying headquarterssubsidiary relations in multinational companies. Journal of International Business Studies, 46(1): 104-113.

Johanson, J., \& Vahlne, J. E. 1977. The internationalization process of the firm: a model of knowledge development and increasing foreign market commitments. Journal of International Business Studies, 8(1): 23-32.

Kaufmann, D., Kraay, A., \& Mastruzzi, M. 2005. Governance Matters IV: Governance Indicators for 19962004: World Bank.

Kogut, B. 1993. Learning, or the importance of being inert: Country imprinting and international competition. In Ghoshal, S \& E Westney, (Eds.), Organization theory and the multinational corporation. New York: St. Martin's Press. 
Kogut, B., \& Singh, H. 1988. The effect of national culture on the choice of entry mode. Journal of International Business Studies, 19(3): 411-432.

Kostova, T. 1999. Transnational transfer of strategic organisational practices: a contextual perspective. Academy of Management Review, 24(2): 308-324.

Kostova, T., \& Roth, K. 2002. Adoption of an organizational practice by subsidiaries of multinational corporations: institutional and relational effects. Academy of Management Journal, 45(1): 215-233.

Kostova, T., Roth, K., \& Dacin, M. T. 2008. Institutional theory in the study of multinational corporations: A critique and new directions. Academy of Management Review, 33(4): 994-1006.

Kostova, T., \& Zaheer, S. 1999. Organizational legitimacy under conditions of complexity: the case of the multinational enterprise. Academy of Management Review, 24(1): 64-81.

Kuemmerle, W. T. J. 1999. The drivers of foreign direct investment into research and development: an empirical investigation. Journal of International Business Studies, 30(1): 1-24.

Luo, Y. 2002. Corruption and organization in Asian management systems. Asia Pacific Journal of Management, 19(2-3): 405-422.

Luo, Y. 2005. An organizational perspective of corruption. Management and Organization Review, 1(1): $119-154$.

Luo, Y. 2011. Strategic Responses to Perceived Corruption in an Emerging Market: Lessons From MNEs Investing in China. Business \& Society, 50(2): 350-387.

Luo, Y., \& Shenkar, O. 2011. Toward a perspective of cultural friction in international business. Journal of International Management, 17(1): 1-14.

Makino, S., \& Delios, A. 1996. Local knowledge transfer and performance implications for alliance formation in Asia. Journal of International Business Studies, 27(5): 905-927.

Mudambi, R., Piscitello, L., \& Rabbiosi, L. 2014. Reverse knowledge transfer in MNEs: subsidiary innovativeness and entry modes. Long Range Planning, 47(1-2): 49-63.

Newenham-Kahindi, A., \& Stevens, C. E. 2017. An institutional logics approach to liability of foreignness: The case of mining MNEs in Sub-Saharan Africa. Journal of International Business Studies, DOI: https://doi.org/10.1057/s41267-017-0111-y

Nobel, R., \& Birkinshaw, J. 1998. Innovation in multinational corporations: control and communication patterns in international R\&D operations. Strategic Management Journal 19(5): 479-496.

Nohria, N., \& Ghoshal, S. 1997. The differentiated network: organizing multinational corporations for value creation. San Francisco, CA: Jossey-Bass Publishers.

Pavitt, K. L. R. 1984. Sectoral patterns of technical change: towards a taxonomy and a theory. Research Policy, 13(6): 343-373.

Rodriguez, P., Uhlenbruck, K., \& Eden, L. 2005. Government corruption and the entry strategies of multinationals. Academy of Management Review, 30(2): 383-396. 
Rosenzweig, P. M., \& Singh, J. V. 1991. Organizational environments and the multinational enterprises. Academy of Management Review, 16(2): 340-361.

Santangelo, G. D., \& Meyer, K. E. 2011. Extending the internationalization process model: Increases and decreases of MNE commitment in emerging economies. Journal of International Business Studies, 42(7): 894-909.

Santangelo, G. D., Meyer, K. E., \& Jindra, B. 2016. MNE subsidiaries' outsourcing and insourcing of R\&D: The role of local institutions. Global Strategy Journal, 6(4): 247-268.

Sartor, M. A., \& Beamish, P. W. 2018. Host market government corruption and the equity-based foreign entry strategies of multinational enterprises. Journal of International Business Studies, 49(3): 346-370.

Siegel, J. I., Licht, A. N., \& Schwartz, S. H. 2013. Egalitarianism, cultural distance, and foreign direct investmetns: A new approach. Organization Science, 24(4): 1174-1194.

Spencer, J. W., \& Gomez, C. 2011. MNEs and corruption: the impact of national institutions and subsidiary strategy. Strategic Management Journal, 32(3): 280-300.

Tsang, E. W. K., \& Yip, P. S. L. 2007. Economic distance and the survival of foreign direct investments. Academy of Management Journal, 50(5): 1156-1168.

Uhlenbruck, K., Rodriguez, P., Doh, J., \& Eden, L. 2006. The impact of corruption on entry strategy: Evidence from telecommunication projects in emerging economies. Organization Science, 17(3): 402-414.

Wang, S. L., Luo, Y., Lu, X., Sun, J., \& Maksimov, V. 2014. Autonomy delegation to foreign subsidiaries: An enabling mechanism for emerging-market multinationals. Journal of International Business Studies, 45(2): 111-130.

Wei, S. 2000. How taxing is corruption on inter-national investors? The Review of Economic and Statistics, 81(1): 1-11.

Westney, E. D., \& Zaheer, S. 2001. The multinational enterprises as an organization. In Rugman, Alan M. \& Thomas L. Brewer, (Eds.), The Oxford handbook of international business. New York: Oxford University Press.

Zaheer, S., Schomaker, M., \& Nachum, L. 2012. Distance without direction: Restoring credibility to a much-loved construct. Journal of International Business Studies, 43(1): 18-27. 
Table 1 - Descriptive statistics and correlation matrix $(N=261)$

\begin{tabular}{llllllllllllllllll}
1 & 2 & 3 & 4 & 5 & 6 & 7 & 8 & 9 & 10 & 11 & 12 & 13 & 14 & 15 & 16 & 17 & 18 \\
\hline
\end{tabular}

\begin{tabular}{|c|c|c|c|c|c|c|c|c|c|c|c|c|c|c|c|c|c|c|}
\hline \multicolumn{19}{|l|}{1 Subsidiary autonomy } \\
\hline 2 Positive corruption distance & 0.17 & & & & & & & & & & & & & & & & & \\
\hline 3 Negative corruption distance & -0.02 & -0.56 & & & & & & & & & & & & & & & & \\
\hline 4 Internal communication & -0.20 & -0.06 & -0.02 & & & & & & & & & & & & & & & \\
\hline 5 MNE experience in corrupt countries & -0.14 & 0.10 & -0.07 & 0.31 & & & & & & & & & & & & & & \\
\hline 6 Subsidiary age & 0.14 & 0.06 & 0.02 & -0.01 & 0.09 & & & & & & & & & & & & & \\
\hline 7 Subsidiary size & -0.06 & -0.06 & 0.16 & 0.07 & 0.39 & 0.03 & & & & & & & & & & & & \\
\hline 8 High-tech industries & -0.07 & 0.07 & -0.03 & 0.10 & -0.23 & -0.01 & -0.16 & & & & & & & & & & & \\
\hline 9 Greenfield & 0.12 & 0.16 & -0.11 & 0.08 & -0.05 & 0.20 & -0.15 & 0.12 & & & & & & & & & & \\
\hline 10 Innovator & 0.23 & 0.15 & 0.14 & -0.11 & -0.19 & -0.03 & -0.02 & 0.09 & -0.07 & & & & & & & & & \\
\hline 11 Contributor & -0.05 & -0.06 & -0.03 & 0.07 & -0.02 & 0.04 & 0.05 & 0.04 & 0.15 & -0.29 & & & & & & & & \\
\hline 12 Implementer & -0.18 & -0.09 & -0.11 & 0.05 & 0.19 & 0.00 & -0.03 & -0.11 & -0.04 & -0.71 & -0.47 & & & & & & & \\
\hline 13 Knowledge flows & 0.12 & -0.03 & 0.08 & 0.02 & 0.11 & 0.12 & 0.06 & -0.02 & 0.12 & -0.07 & -0.12 & 0.16 & & & & & & \\
\hline 14Cultural distance & -0.10 & -0.03 & -0.29 & 0.05 & 0.01 & -0.23 & -0.17 & 0.08 & 0.02 & -0.22 & 0.00 & 0.21 & 0.00 & & & & & \\
\hline 15 Geographical distance & 0.06 & 0.48 & -0.47 & 0.01 & 0.05 & 0.10 & -0.13 & 0.18 & 0.17 & -0.05 & 0.09 & -0.02 & -0.05 & 0.04 & & & & \\
\hline 16Economic distance & 0.09 & -0.04 & 0.43 & -0.08 & -0.06 & 0.13 & 0.13 & -0.03 & -0.07 & 0.34 & -0.04 & -0.28 & 0.01 & -0.46 & -0.46 & & & \\
\hline 17 IPR distance & 0.07 & -0.10 & 0.58 & -0.08 & -0.07 & 0.14 & 0.18 & -0.01 & -0.09 & 0.33 & -0.05 & -0.27 & 0.04 & -0.56 & -0.47 & 0.91 & & \\
\hline 18 Knowledge sourcing opportunities & 0.06 & 0.34 & 0.10 & -0.14 & -0.01 & -0.05 & 0.03 & 0.07 & -0.01 & 0.22 & -0.02 & -0.19 & -0.01 & 0.13 & 0.04 & 0.45 & 0.43 & \\
\hline Mean & 2.46 & 0.49 & 0.83 & 3.79 & 3.13 & 2.04 & 0.05 & 0.39 & 0.32 & 0.30 & 0.16 & 0.54 & 0.84 & 1.09 & 3.49 & -0.38 & 0.52 & 0.72 \\
\hline S.D. & 0.75 & 0.82 & 0.89 & 1.40 & 3.33 & 0.73 & 0.15 & 0.49 & 0.47 & 0.46 & 0.37 & 0.50 & 0.37 & 0.86 & 3.30 & 1.02 & 1.69 & 0.96 \\
\hline
\end{tabular}

Correlations $>0.09$ are significant at $\mathrm{p}<0.1$. 
Table 2 - Subsidiary autonomy and corruption $(N=261)$

\begin{tabular}{|c|c|c|c|c|c|c|c|c|c|c|}
\hline \multirow[b]{2}{*}{ Positive corruption distance } & \multicolumn{2}{|c|}{ Model 1} & \multicolumn{2}{|c|}{ Model 2} & \multicolumn{2}{|c|}{ Model 3} & \multicolumn{2}{|c|}{ Model 4} & \multicolumn{2}{|c|}{ Model $5^{b}$} \\
\hline & $0.169 * *$ & $(0.073)$ & $0.163 * *$ & $(0.064)$ & $0.169 * *$ & $(0.072)$ & $0.163 * *$ & $(0.064)$ & $0.184 * *$ & $(0.071)$ \\
\hline Negative corruption distance & 0.064 & $(0.073)$ & 0.072 & $(0.074)$ & 0.063 & $(0.073)$ & 0.073 & $(0.074)$ & 0.072 & $(0.078)$ \\
\hline Internal communication & -0.074 & $(0.064)$ & -0.085 & $(0.061)$ & -0.077 & $(0.068)$ & -0.083 & $(0.064)$ & 0.027 & $(0.050)$ \\
\hline MNE experience in corrupt countries & -0.027 & $(0.020)$ & -0.029 & $(0.020)$ & -0.025 & $(0.025)$ & -0.031 & $(0.024)$ & $-0.047 * *$ & $(0.021)$ \\
\hline Positive corruption distance $\times$ Internal communication ${ }^{a}$ & & & $-0.105^{* *}$ & $(0.046)$ & & & $-0.108 * *$ & $(0.050)$ & $-0.084 *$ & $(0.045)$ \\
\hline Positive corruption distance $\times$ MNE experience in corrupt countries ${ }^{\text {a }}$ & & & & & -0.005 & $(0.012)$ & 0.003 & $(0.012)$ & & \\
\hline Subsidiary age & 0.105 & $(0.098)$ & 0.114 & $(0.098)$ & 0.106 & $(0.100)$ & 0.113 & $(0.099)$ & 0.122 & $(0.099)$ \\
\hline Subsidiary size & -0.033 & $(0.327)$ & -0.041 & $(0.300)$ & -0.051 & $(0.363)$ & -0.030 & $(0.328)$ & 0.003 & $(0.247)$ \\
\hline High-tech industries & -0.178 & $(0.160)$ & -0.185 & $(0.157)$ & -0.173 & $(0.159)$ & -0.188 & $(0.156)$ & -0.240 & $(0.158)$ \\
\hline Greenfield & 0.138 & $(0.142)$ & 0.135 & $(0.140)$ & 0.134 & $(0.145)$ & 0.137 & $(0.142)$ & 0.102 & $(0.152)$ \\
\hline Innovator & $0.352 * *$ & $(0.175)$ & $0.364 * *$ & $(0.175)$ & $0.350 *$ & $(0.177)$ & $0.365 * *$ & $(0.177)$ & $0.357 * *$ & $(0.176)$ \\
\hline Contributor & 0.067 & $(0.158)$ & 0.100 & $(0.152)$ & 0.069 & $(0.158)$ & 0.099 & $(0.152)$ & 0.068 & $(0.136)$ \\
\hline Knowledge flows & $0.275^{*}$ & $(0.147)$ & $0.279 *$ & $(0.147)$ & $0.272 *$ & $(0.147)$ & $0.281 *$ & $(0.145)$ & $0.295^{* *}$ & $(0.139)$ \\
\hline Cultural distance & 0.001 & $(0.052)$ & -0.005 & $(0.052)$ & 0.001 & $(0.052)$ & -0.006 & $(0.052)$ & -0.022 & $(0.052)$ \\
\hline Geographical distance & 0.005 & $(0.021)$ & 0.000 & $(0.020)$ & 0.005 & $(0.021)$ & 0.000 & $(0.020)$ & 0.001 & $(0.019)$ \\
\hline Economic distance & 0.114 & $(0.092)$ & 0.096 & $(0.092)$ & 0.112 & $(0.091)$ & 0.097 & $(0.091)$ & 0.102 & $(0.092)$ \\
\hline IPR distance & -0.071 & $(0.059)$ & -0.071 & $(0.057)$ & -0.068 & $(0.059)$ & -0.073 & $(0.057)$ & -0.081 & $(0.055)$ \\
\hline Knowledge sourcing opportunities & -0.050 & $(0.061)$ & -0.055 & $(0.065)$ & -0.051 & $(0.061)$ & -0.054 & $(0.065)$ & -0.026 & $(0.061)$ \\
\hline Constant & $2.255^{* * *}$ & $(0.320)$ & $2.282 * * *$ & $*(0.312)$ & $2.257 * * *$ & $(0.322)$ & $2.282 * * *$ & $(0.312)$ & $2.021 * * *$ & $(0.251)$ \\
\hline F-Test & $2.71 * * *$ & & $2.80 * * *$ & & $2.65 * * *$ & & $2.69 * * *$ & & $2.470 * * *$ & \\
\hline R-squared & 0.174 & & 0.194 & & 0.175 & & 0.194 & & 0.173 & \\
\hline
\end{tabular}

Notes: Robust standard errors (in parentheses) corrected for MNE cluster-correlated data.

a The interacting variables were normalized around their mean value before being interacted.

${ }^{\mathrm{b}}$ Internal communication is measured as the residuals $(\hat{\varepsilon})$ of the model internal communication $=\alpha+\beta$ subsidiary autonomy $+\varepsilon$. The residuals variable was normalized and interacted with positive corruption distance.

$* \mathrm{p}<0.10 ; * * \mathrm{p}<0.05 ; * * * \mathrm{p}<0.01$ (two-tailed tests applied). 


\section{Figure 1 - The moderating effect of HQ-subsidiary communication}

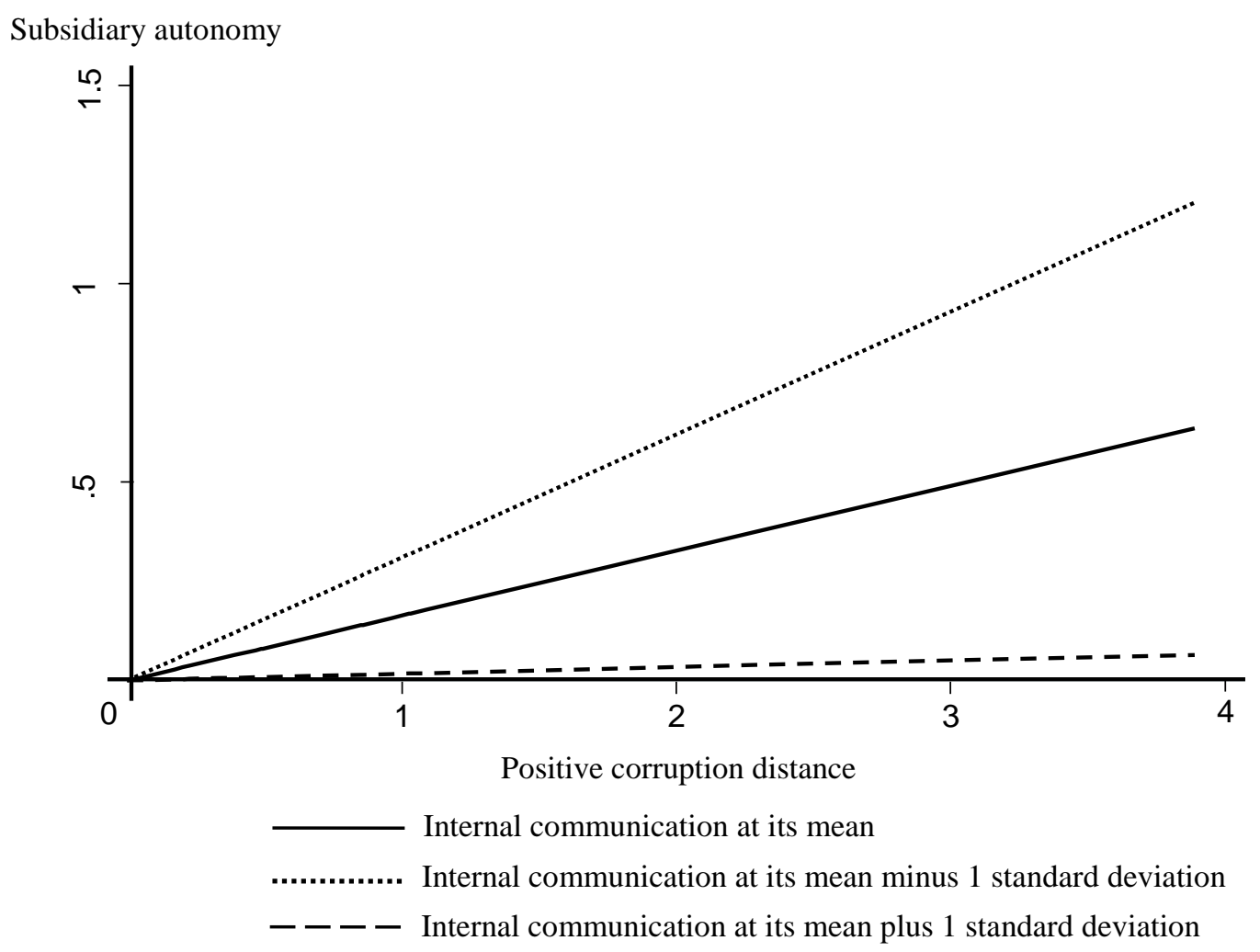

